anonymous, if we please, but which was referred by every one who read it to the Astronomer-Royal for Scotland, who showed not the slightest wish to conceal his identity. Doubtless on hearsay evidence (in which, however, he placed, I am sure, as much reliance as I placed in his own statement), Prof. Smyth asserted that Newcomb had anticipated Stone's labours. I took it for granted that it was so, since I saw no room or reason for doubt. There was my error. But, says Prof. Newcomb, whence comes the value 8".87 "which it will be noted is Mr. Petrie's pyramid value?" and on what does $\mathrm{Mr}$. Proctor found his comments "about my treatment of contacts? I am as much in the dark as ever." I will tell him. The value $8^{\prime \prime} 87$ has nothing on earth to do (so far as I am concenned) with Mr. Petiie's pyumid value. It is simply the value insisted upon by prof. Newcomb in a paper which appeared in the Monthly Notices of the Royal Astronomical Society for November I868; respecting which Mr. Stone remarked (see the same number of the Notices) that "the point $M$. Newcomb has raised is a question of only $\mathrm{o}^{\prime \prime} \cdot \mathrm{O}_{4}$, viz. between my value and $8^{\prime \prime} \cdot 87$-a question, therefore, of comparative insignificance." Most just remark! With my belief as to Prof. Newcomb's prior work, was it wonderful that I concluded that $8^{\prime \prime} .87$ was his own pet figure for the parallax? Then it chanced that the Royal Astronomical Society, venturing to ignore Prof. Newcomb's objections, bestowed on Mr. Stone, in 1869 , the Gold Medal of the Society for his researches into the Venus transit; and in the remarks which accompanied the presentation, it was stated that all preceling researches were imperfect in this respect, that (to use my own words) "no fixed rule had been adopted for interpreting the observations of internal contact." Prof. Newcomb cannot fail to see how this statement accounts for the estimate (not my estimate) of his supposed researches.

As a matter of fact, however-apart from the inference to which Prof. Newcomb is so anxious to give point-I am somewhat hardly treated in this matter. When I came to the part of my book where Prof. Newcomb's supposed researches should be dealt with, I thought thus in my mind: "Assuredly Newcomb has done this thing for Prof. Smyth says so. Shall I leave his researches umnoticed because I can find no trace of them? That would be scarcely fair. Moreover, he is an American, and to omit all notice of his work will be so much the more objectionable. Verily I will repeat the statement of my esteemed friend at Edinburgh, and I will combine with it the weighty judgment of my friends at the council-board of the Astronomical Society. Thus will the researches of Newcomb be recorded, and due credit be assigned to him for his industry and skill, while yet no undue weight will be given to the mumerical result of his labours."

That I thus fell into error I have already admitted. But the error is venial in its nature, and utterly insignificant in its effects. As I am conscious that it arose chiefly from my desire (shown in other ways and places) to do justice to our American fellowworkers in science, I am in no way ashamed of it; and I conceive that Prof. Newcomb should have been the last to comment in the manner he has done on the subject.

I shall not follow him in his discussion respecting irradiation, leaving Mr. Stone to deal, in his own good time, with the arouments by which two Continental astronomers (and one American mathematician) have sought to deprive him of his justly-earned credit.

I would submit, in conclusion, that February 1869 (the date of the presentation of the Astronomical Society's medal to Mr. Stone) can scarcely be described as "five years" ago even now, and my treatise on the sun was published in February 1871 , Chapter I. being in type in November 1870 . Nor has the council of the Astronomical Society (or any member of it) expressed any donbt, as yet, regarding the jnstice of the decision arrived at in 1860. Yet not a few members of the council have paid marked attention to Prof. Newcomb's attacks upon Mr. Stone. Verbum sat.

Brighton, Nov, 24

\section{The Density and Depth of the Solar Atmosphere}

THE demonstration relating to the density and depth of the solar atmosphere, published in NATURE October 5, $187 x$, page 449, has been entirely misconceived by Mr. Ball. The volume of the terrestrial atmosphere is an element which obviously has nothing to do with the question. Atmospheric air, if raised to a temperature of $3,272,000^{\circ} \mathrm{Fah}$., will expand 6,643 times ; hence a vertical column forty-two miles high will reach a height of
279.006 miles, if brought to the stated temperature. The basis of computation adopted by Captain Ericsson heing an area of one square inch, he shows that a medium similar to the terrestrial atmosphere containing an equal quantity of matter for corresponding area, transferred to the solar surface, will, owing to the superior attraction of the sun's mass, exert a pressure of $14.7 \times$ $279=4$ Io pounds. And that, if the said medium be heated to a mean temperature of $3,272,000^{\circ} \mathrm{F}$ ah., it will expand to a height of $279^{\circ} 006$

$\frac{279}{29}=10,000$ miles above the solar surface. But, if a gas composed chiefly of hydrogen I' 4 times heavier than hydrogen the specific gravity of which is $\frac{1}{14}$ of that of air, be substituted, the height will be $\frac{r_{4} \times 10,000}{14}=100,000$ miles. Admitting that the ascertained coefficient of expansion, 0.00203 for $\mathrm{I}^{\circ} \mathrm{Fab}$., holds good at the high temperature before referred to, the stated altitudes of the solar atmosphere cannot be disputed. Mr. Ball's announcement concerning the properties of spheres, it is scarcely necessary to observe, has no bearing on the foregoing calculations. With reference to the effect of intenve heat, it will be well to bear in mind that the before-mentioned rate of expansion holds good for atmospheric air-within an insignificant fraction--under extreme rarefaction as well as under high temperatures. We have no valid reason, therefore, to suppose that any deviation from the ascertained law of expansion takes place in the solar atmosphere, sufficient to alter materially the before-mentioned computations of its depth.

Mr. Ball, in expressing the opinion that we shall not gain much correct knowledge of the solar atmosphere by the inquiry instituted by Captain Ericsson. forgets thar the retardation which the radiant heat suffers in passing through our atmosphere has been ascertained, and that the properties of atmospheric air with reference to temperature and expansion are nearly identical with those of hydrogen, now admitted to be the chief constitnent of the solar atmosphere. It is evident that $\mathrm{Mr}$. Ball does not comprehend the object of adopting the terrestrial atmosphere as a means of determining the extent and depth of the solar atmosphere, since he does not perceive that the comparison instituted by Captain Ericsson has brought out the fact that either the depth. of the sun's atmosphere exceeds 100,000 miles, or it contains less gaseous matter than the earth's atmosphere for equal area. The importance of this conclusion with regard to the determination of the retardation of the radiant heat in passing through the sun's atmosphere is self-evident to all who regard solar radiation as energy which cannot be absorbed unless an adequate amount of matter be present. Mr. Ball's suggestion that the retardation depends on the "chemical, i.e. molecular-constitution" of the solar atmosphere, calls to mind how libly some physicists talk of "arresting" one half, or more, of the solar energy. These reasoners apparently do not perceive that the means of arresting such stupendous energy is more difficult to conceive than the means of producing it.

Respecting the experiments which have been made with itcandescent cast-iron spheres, and inclined discs, it is important to mention that previous experiments had established the fact that the radiant heat of flames transmits equal temperature, under similar conditions, as incandescent cast iron. The inference, therefore, which has been drawn by Captain Ericsson from the results of his experiments with incandescent cast-iron spheres regarding the feebleness of radiant heat emanating from the sun's border is not un warrantable as supposed by Mr. Ball.

New York, Nov, Io

THULE

\section{An Aberrant Foraminifer}

I CHANCED upon an aberrant form of Peneroplis the other day, in which the free terminal series of chambers of this Foraminifer, ordinarily single, is constricted into two distinct tubes.

Though new to me, it may not be su to some of your readers; Dr. Carpenter, however, does not mention it in his monograph.

St. John's College, Cambridge

W. JOHNSON SOLLAS

\section{"New Original Observation"}

ERNST FRIEDINGLR, of Vienna, begins a communication on the subject of "which cells in the gastric glands secrete the 
pensine?"** as follows :-_" Kölliker erwähnt zuerst das Vorkommen von zweierlei Zellen in den Pepsindrïsen des Hundes." "On referring to Kölliker I find, "Bei Thieren sind, wie Todd-Bowman zuerst beim Hunde, ich and Donders bei vielen andern Säugern gezeigt haben, die Magendrüsen iiberall doppeiter Art," \&c. In Todd and Bowman, published some years before this, the two kinds of glands are figured (the drawings being better than those of Kolliker), the difference between them in anatomical characters, the difference of the two parts of the gland, and the difference in the function discharged by the two kinds of cells of each of the two kinds of glands, pointed out. Friedinger does not even mention the names of the English observers.

I. S. B.

\section{New Zealand Forest-Trees}

IN your paper of Nov. 9 I observed a letter about New Zealand Forest.Trees, signed by Mr. John R. Jackson of Kew.

Mr. Jackson refers to several of the magnificent varieties of forest trees belonging to the natural order of Conifere, which are widely distributed in New Zealand; omiting, however, some of the most common and most valuable, especially the Kahikatea or "white pine" of the settlers. This tree affords timber of a white colour, much like yellow deal in appearance and cuality, which is admirably adapted for use as weatherboard, flooring-boards, and scantling for all in-door work as well as for ordinary furniture. It is most extensively used for all those purposes. The "Totara" is particularly used for making shingles, which form a good substitute for slates as a covering for roofs.

The Rimu is used for such work as requires a more durable wood, and for the making of superior furniture, the wood being much harder and more difficult to work, than that of the Kahikatea, while its beautiful colonr renders it very suitable for ordinary cabinet work.

Varietis of the acacia, called Kowai by the natives, supply timber wh ich is specially adapted for the making of pales and fericing, and which is as durable as English oak; and there are many varieties of trees suitable for all purposes.

It is, however, in reference to that which is mentioned as the "Makia" that I think it worth while to trouble you, as I believe that I may be able to suggest what the word so referred to really is. I know of no tree or shrub so called, but Manuka, pronounced Manooka, is the name of the tree from which the naives in former times used to make all sorts of implements, especially the spears, which formed at once the weapons and the sceptres of the chiefs. That hardly deserves to be called a forest-tree, as it rarely attains any great size.

It belongs, I believe, to the family of "Diosma," and its wood is used to make axe-handles, ramrods for guns, \&c. The leaves have a pleasant aromatic odour, and an infusion of them forms a passable substitute for tea, to which we were frequently glad to resort in the early times of New Zealand settlements. The fresh twigs form an elastic couch, which constituted our favourite bed on exploring parties and in temporary dwellings.

Braintree, Nov. 20

WILLIAM DAVISON

\section{The Food of Plants}

Your reviewer takes exception to my empirical description of carbonic acid in "Notes on the Food of Plants," p. 23. I readily admit-and I should have thought it was unnecessary to do sothat to describe carbonic acid as "carbon dioxide combined with water" is not strictly correct ; but I think it is much more likely that I should have led my unscientific readers astray, had I explained, in more accurate language, the supposed composition of this acid.

CUTHBERT C. GRUNDY

\section{The Germ Theory of Disease}

Is Nature, October 5, p. 450, Prof. Bastian, zersus the Germ Theory, says:- "Such germs when present would be sure to go on increasing until they brought about the death of their host." Now, is it not well known that the larva of Trichina spiralis become encysted in the muscles of the animal infested by them, and are then perfectly harmless to their host, the fever, sometimes with fatal results, being produced by the

* Aus dem Ixiv. Bande der Sitzb. der k. Akad. der Wissensch. II. Abth. Oet. - Heft. Jahrg. $187 \mathrm{r}$. migration of the parasites from the alimentary canal through the tissues to their favourite muscles.

Is it necessary, for the support of the germ theory, that the organism must be found in the blood?

Balbriggan, Ireland, Nov. 20

GEORGE DAWSTN

\section{The Origin of Species}

SOME months since a letter appeared in NATUKE, asking the author of the article on "The Origin of Species," published in the North Britis/ Review, 1867, to explain the following passage which occurs in the article :- "A million creatures are born; ten thousand survive to produce offspring. One of the million has twice as good a chance as any other of surviving, but the chances are fifty to one against the gifted individuals being one of the hundved survivors." There is an error in this passage; the word "hundred "shonld be altered to "ten thousand." I presume that with this correction the writer of the letter will have no difficulty in following the argument. I am much obliged to him for drawing my attention to the slip.

The AUthor or the ARticle

\section{NEW VOLCANO IN THE PHILIPPINES}

THE island of Camiguin is situated to the north of Mindanao, at some six or eight miles from the coast, is only a few miles in circumference, and consists principally of high land. On the slopes and in the valleys is grown a large quantity of one of the most important staples of the Archipelago, the well-known Manila Hemp - the fibre of the Musa textilis.

On the first of May, I87I, after a series of violent earthquakes, a volcano burst out in a valley near the sea. The earth is said to have swelled, cracked, and then opened, ejecting large quantities of stones, sand, and ashes, but no liquid lava. The mischief done by the eruption was limited to a small area of two or tbree miles in extent, and the loss of life did not exceed eighty or ninety persons, who might have escaped if they had been less anxious to save their little property.

As the eruption and volcanic disturbances continued for some time, the alarmed natives abandoned the island in great numbers, and took refuge in the neighbouring islands of Mindanao, Bohol, \&c., from which, after some weeks, the eruption having subsided, most of them returned. During the month of June the volcano ejected smoke and scoria, which latter are said to have been slowly pushed up as it were out of the crater, sliding down the sides over an underlying mass of fine grey ashes which were thrown out in the first instance; and a feeble action has continued by the latest accounts (August).

The eruption, instead of bursting from the top or sides of the higher hills, occurred in a valley between two spurs of high land near the sea and in the immediate neighbourhood of one of the principal villages, which the inhabitants abandoned, and do not seem disposed to reoccupy, though the damage done there was trifling.

As is usual here, the stories circulated were of the most exaggerated kind, and it is only by sifting and comparing the accounts of reliable eye-witnesses that I have been able to write an account at all worthy of attention. The observations made by two intelligent persons, who visited the island expressly for the purpose, have furnished the materials for this memorandum. The accounts as to the height of the cone are mere guesses-from 300 to 1,500 feet. H.M. surveying steamer Nassau, Captain Chimmo, is said to have visited the island in June, and we may therefore hope for a careful and scientific account of this phenomenon.

The present year has been remarkable for the extent and frequency of earthquakes over the whole of the Archipelago, though, with the exception of the case of Camiguin, they were not followed by any very serious consequences. Manila, Sept. 25
WM. W. WOOD 